\title{
An Evaluation of English Textbooks in Japan from the Viewpoint of Nations in the Inner, Outer, and Expanding Circles
}

\author{
Nobuko Yamanaka \\ Ehime University
}

English is used as an international language in communicating with people across many cultures in the modern world. Kachru has investigated this phenomenon and created the "three concentric circles" model to portray the global diffusion of English. His findings show that the "cultural dimensions" of English usage have been expanding; as a result, it is important for Japanese English learners to understand as wide a variety of cultures as possible for effective intercultural interactions. In Japan, the Ministry of Education, Culture, Sports, Science and Technology maintains that "the understanding of cultures" should be regarded as one of the main objectives in teaching English at the secondary school level. However, as there are few specific instructions provided in terms of the teaching of culture, it is difficult to understand which nations should be included in the teaching of English. This paper, therefore, aims to help us understand which countries are currently included in junior high and senior high school English textbooks based on Kachru's three-concentric-circles model.

英語は現在、異文化間で行われるコミュニケーションのさまざまな場面で国際語として 機能している。Kachru (1989)は調査結果に基づき、このような英語の世界的な広まりを説 明するために Three Concentric Circles モデルを提唱した。このモデルが示しているのは、 英語が広く使われるようになるということはすなわち文化の次元の広がりを意味するとい うことである。その結果、英語で効果的なコミュニケーションを行うために英語学習者は 英語圈の文化のみならず、異文化に関する幅広い知識を持つことが重要になるのである。 異文化理解は日本の中学校、高等学校英語教育において最も重要な目標の1つに挙げられ ている。しかしながら、指導の場面でどの文化を含めるべきか、また実際に含めているの かを具体的に把握するのは難しい。こうした現状をふまえ、本論は中学校、高等学校の英 語教科書を一定の枠組みで分析し、さらに Three Concentric Circles モデル に基づいて、 the Inner Circle、 the Outer Circle、Expanding Circle の3つのカテゴリーに分類した。結果を もとに日本の英語教育における異文化理解を考察した。

JALT Journal, Vol. 28, No. 1, May, 2006 
“Originally English was only a small dialect brought to Britain by Anglo-Saxons in the 5th century, but now it has attained the status of the world's most common language" (Horibe, 2000, p. 327).

As the global lingua franca, English functions as an international language between people across a wide variety of cultures. In investigating this phenomenon, Kachru (1989) has created a model of "three concentric circles" of English which can be illustrated as follows:

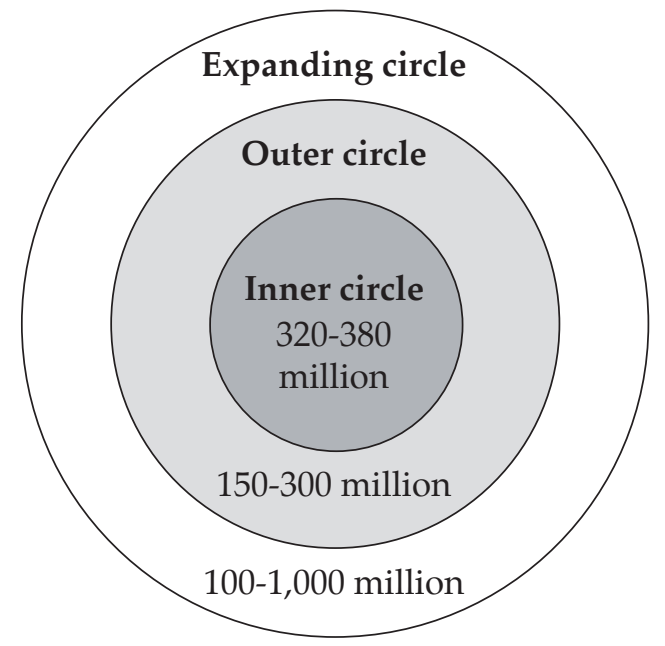

Figure 1. The Three Circles of English

Adapted from English as a Global Language (Crystal, 1997)

Kachru (1989, p. 16) states, "these circles represent the types of spread, the patterns of acquisition, and the functional allocation of English in diverse cultural contexts." In his framework, English speakers are classified into three groups: the Inner Circle for "the traditional cultural and linguistic bases of English" (Kachru, 1989), the Outer Circle for "the institutionalized usage of English" (Kachru, 1989), and the Expanding Circle for users of "English as an international language" (Crystal, 1997, p. 54). The population figures in this model are an estimate of the number of English speakers in each grouping. As can be seen, the total number of English speakers in the Outer and Expanding Circles is far greater than that in the Inner Circle. In other words, a large number of people in many different countries throughout the world use English for communication, and 
although there is still a great deal of debate on this matter, it is becoming clear that the "cultural dimensions" of English use and usage have been expanding globally. As a consequence, there is a need to include as wide a variety of cultural elements as possible in teaching and learning English in order for Japanese students to communicate effectively with people from other countries.

The Ministry of Education ${ }^{1}$ also provides guidelines for the teaching of cultural elements in secondary schools, stating that the understanding of cultures is one of the main objectives for both Japanese junior high and senior high school students. The Ministry requires that junior high school teachers "take up a variety of suitable topics in accordance with the level of students' mental and physical development, as well as their interests and concerns, covering topics... of Japanese people and the peoples of the world, focusing on countries that use English" (Ministry of Education, Culture, Sports, Science and Technology, 2003, pp. 5-6). Since English is not compulsory at senior high schools, the word "English" is replaced with "foreign languages" (2003, p. 14), although most senior high schools offering foreign language education choose English as the language for students.

However, this statement is rather ambiguous in two respects. Firstly, according to the guidelines above, teachers have to consider "the level of students' mental and physical development" in choosing among many cultural topics pertaining to various nations, despite the fact that there are no specific instructions for the evaluation of their students' physical and mental maturity which they can refer to in selecting their teaching items. It would be useful if detailed directives were supplied to teachers according to the developmental stages of junior high and senior high school students. Secondly, although the Ministry requires that teachers focus on "countries that use English," from a practical standpoint, it is difficult to determine which individual nations should be included in teaching materials as an appropriate source of culture related to English in Japanese curricula. Should the requirement to "focus on countries that use English" be fulfilled by concentrating on nations of the Inner, Outer, or Expanding Circles?

Thus, the information contained in the Ministry's guidelines is lacking in specificity; nevertheless, some regard the inclusion of cultural topics or items alluding to nations of the world as significant in cultivating students' understanding of cultures through the medium of English. Indeed, Ashikaga, Fujita, and Ikuta (2001) advocate that "textbooks used for teaching English as a foreign language (EFL) can be primary sources for students to obtain cultural knowledge" (p. 2), pointing out that "the 
teaching of cultural content is extensively influenced by textbook content" (p. 8). Browne and Wada also conducted an exploratory survey on English teachers in Japan in terms of primary elements that can affect their classroom performance. The results show that "teachers feel compelled to teach the... [English] textbooks" and that teaching the contents of the textbooks is considered the "largest pressure on classroom teaching" (1998, p. 105). Hence, not only do English textbooks have a great influence on students' understanding of cultures, they also influence teachers' classroom performance.

Therefore, a detailed analysis of these textbooks can provide valuable insights into the current teaching of culture from the standpoint of which countries are considered important in Japanese education. A number of textbook assessments have been conducted from various viewpoints. For instance, Kitao evaluated Japanese senior high school English textbooks from the perspective of American culture and based his evaluation on cultural items suggested by the Ministry of Education (Kitao, 1979, p. 93) such as "daily life, manners and customs, geography and history." He also outlined cultural elements found in English textbooks for junior high school students on the basis of previous studies. Ashikaga et al. (2001) examined English textbooks for senior high school students, creating four categories $^{2}$ for analysis. Sochi (2001) investigated dialogues appearing in English textbooks for junior high school students from the standpoint of nations, focusing in particular on the nature of the characters (i.e., the people) and the topics they discuss.

The results of these studies offer important information for contemporary researchers, but there are some shortcomings. Firstly, since most investigators have examined English textbooks only for junior high school or only for senior high school students, each from a specific point of view, it is not possible to integrate these results into a single analytical framework which takes into account students' levels of maturity throughout secondary school. On the basis of these fragmented data, therefore, it is quite difficult to determine what Japanese students are supposed to learn in terms of culture as it is related to various nations by examining the English textbooks used during the entire six years of the secondary school period. Although Kitao (1979) investigated English textbooks for both levels of students, his methodology employed two types of analysis: secondary research and primary research. The secondary research included an investigation of one previous study analyzing English textbooks for senior high schools as well as four previous studies of junior high school English textbooks, all from the stand point of culture. 
The primary research, on the other hand, is in the form of an analysis of English textbooks for senior high school students, but only in terms of American culture. Secondly, most of these studies have not utilized the three concentric circles concept (Kachru, 1989) which was created to portray the diffusion of English speakers throughout the world. These two shortcomings make it difficult to evaluate the teaching of culture on the basis of a single analytical framework.

However, one study by Kiryu, Shibata, Tagatani, and Wada (1999) did make use of Kachru's model in creating two categories ${ }^{3}$ for textbook analysis, emphasizing the perspective of English as an international language. The results of their study were tabulated from the standpoint of individual countries, regions, and the three concentric circles proposed by Kachru. Although the findings of Kiryu et al. have provided useful information, their model for textbook analysis does not allow us to understand the teaching of culture in terms of individual countries according to students' developmental progress through junior high school into senior high school because they only examined English textbooks for senior high school students, stating that "in most previous research, since English textbooks for junior high school have been chosen as the target materials, there is little research on English textbooks for senior high school; therefore, it would be significant to examine which nonnative countries of English have been found in English textbooks at the senior high school level" (Kiryu et al., 1999, p. 21; my translation).

In order to reach an understanding of which countries are considered important in Japanese English education, it is necessary to evaluate teaching materials used throughout secondary school on the basis of a single analytical framework. The purpose of this paper, therefore, is to provide such an understanding by analyzing English textbooks for both junior high and senior high school based on one framework-Kachru's three-concentric-circles model.

\section{Method}

\section{Materials}

Nineteen English textbooks were selected for this study and evaluated at the lesson or unit level. All of them have been approved by the Ministry of Education and are used at secondary schools in Japan. For junior high schools, three English textbooks used for all grades were chosen: New Crown (21\%), New Horizon (41.0\%), and Sunshine English Course (data unavailable). The percentages in parentheses were reported by each 
publishing company. Although the exact percentage of use for Sunshine English Course is not available at present, approximately $85 \%$ of schools at this level in Japan have chosen these three textbooks. As for senior high schools, the following ten English textbooks for Eigo I (English I) were selected out of thirty-five volumes listed in Eigo I, as a representative sample of the teaching of culture for this study: Crown English Series I (9.8\%), All Aboard! English I (7.4\%), Vista English Series I (6.9\%), Unicorn English Course I (6.2\%), Power on English I (5.1\%), Milestone English Course I (4.1\%), Vivid English Course I (3.9\%), Pro-vision English Course I (3.9\%), Exceed English Series I (3.7\%), and English Now I (3.6\%). The percentages in parentheses describe the ratios of textbook use by senior high school students in Japan, as published by Naigai Kyouiku (2002, p. 12). Although these ten textbooks only comprise approximately $50 \%$ of the total, they were chosen because they are representative of the most frequently used textbooks in Japanese senior high schools, and should thus provide a clear indication of the nations of which various aspects of culture are being taught at senior high schools. ${ }^{4}$

\section{Procedures}

Since the purpose of this study is to analyze the teaching of culture in terms of various nations from junior high school through senior high school, the focus should be placed on information found in the textbooks as related to individual countries. Therefore, the frequencies of cultural items were examined in all of these English textbooks on the basis of the nations from which various aspects of culture were found. Two criteria were established for analysis at the lesson or unit level: (a) the identification of nouns and adjectives for nations, such as Japan or Japanese; and (b) the identification of other alternative words related to nations, such as expressions indicating certain products and cities or other geographical regions in particular countries (for example, kimono or Tokyo would belong to the category of Japan). When problems arose in making a decision, dictionaries or other sources were consulted in order to distinguish whether a certain item belonged to a particular nation or not. Two fulltime junior high school teachers served as raters. They were also required to undergo preliminary practice sessions using this approach to textbook assessment, as well as to discuss any potential problems in advance. An interrater reliability study was conducted using two external raters and the interrater reliability scores were $r_{1}=1.00$ and $r_{2}=1.00$, respectively, reflecting unanimous agreement. 


\section{Results}

In order to understand tendencies found in English textbooks in the teaching of culture at secondary schools in terms of nations of the world, the results have been tabulated at each grade level according to the "three concentric circles" model proposed by Kachru. Firstly, the nations of each circle have been analyzed individually. Secondly, these results have been evaluated in a variety of ways, highlighting comparisons among the three circles, particularly in relation to Japan.

\section{Nations: Three Circles}

\section{Nations of the Inner Circle}
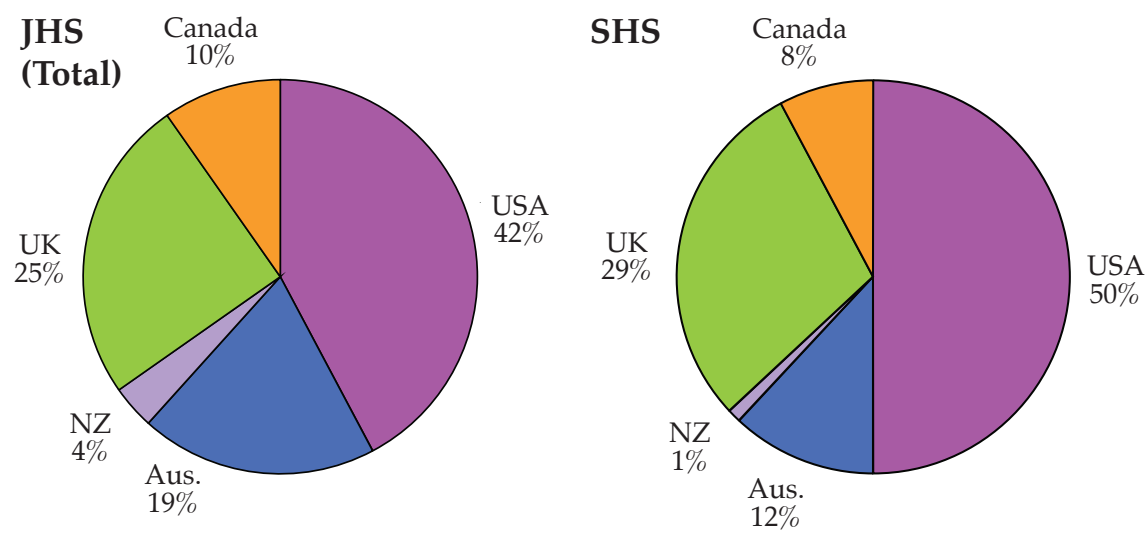

Figure 2. Nations of the Inner Circle

According to Crystal (1997, p. 53), "the inner circle refers to the traditional bases of English, where it is the primary language: it includes the USA, UK, Ireland, Canada, Australia and New Zealand." Table 1 shows the frequencies of these nations for which cultural topics are found in English textbooks in Japan. As can be seen, firstly, the dominant emphasis is on America for all grades of JHS and SHS. Indeed, as Figure 2 illustrates, the USA percentage stands at nearly $42 \%$ for JHS in total and goes up to $50 \%$ in SHS. Secondly, in terms of the other nations, the distributive proportions of the countries of Oceania and the UK are similar for JHS in total, whereas these two regions differ in SHS. Thirdly, in examining English from the standpoint of geographic distributions, Crystal (1997, p. 63) developed "a family tree representation of the way English has spread around the world, 
showing the influence of the two main branches of American and British English." Thus, this tree shows Australian and New Zealand English to have roots in the UK, while Canadian English has been influenced largely by the USA. In evaluating the results in the Inner Circle from the perspective of these two main branches of English, American English stands at $52 \%$ in JHS, then rises slightly to 58\% in SHS. In terms of British English these percentages are $48 \%$ and $42 \%$, respectively.

Table 1. Nations in which Various Aspects of Culture are Found: The Inner Circle

\begin{tabular}{lccccc}
\hline & $\begin{array}{c}\text { 1st year } \\
\text { JHS }^{5}\end{array}$ & $\begin{array}{c}\text { 2nd year } \\
\text { JHS }\end{array}$ & $\begin{array}{c}\text { 3rd year } \\
\text { JHS }\end{array}$ & $\begin{array}{c}\text { Total } \\
\text { JHS }\end{array}$ & SHS \\
\hline USA & 9 & 5 & 8 & 22 & 38 \\
Australia & 6 & 3 & 1 & 10 & 9 \\
Canada & 4 & & 1 & 5 & 6 \\
England & 1 & 2 & 1 & 4 & 11 \\
Scotland & 1 & 1 & & 2 & 3 \\
Britian/UK & & 3 & 1 & 4 & 6 \\
Wales & & 1 & 1 & 2 & 1 \\
New Zealand & & 1 & 1 & 2 & 1 \\
Northern & & 1 & & 1 & 1 \\
Ireland & & & & & \\
\hline
\end{tabular}

\section{Nations of the Outer Circle}

The Outer Circle, which is sometimes referred to as the Extended Circle, "involves the earlier phases of the spread of English in nonnative settings, where the language has become part of a country's chief institutions, and plays an important 'second language' role in a multilingual setting: it includes Singapore, India, Malawi, and over fifty other territories" (Crystal, 1997, pp. 53-54). Table 2 presents the nations of the Outer Circle whose cultural items have been identified in the textbooks. As can be seen in Table 2, these nations seldom appear in JHS, while they are sometimes found in SHS. Unfortunately, although many of these nations are important trading partners for Japan in the modern world (for exam- 
ple, Singapore was the first country to conclude a free-trade agreement with Japan in 2002 (First Step, 2004)), little information on these countries is available to students through English textbooks.

Table 2. Nations in which Various Aspects of Culture are Found: The Outer Circle

\begin{tabular}{lccccc}
\hline & $\begin{array}{c}\text { 1st year } \\
\text { JHS }^{5}\end{array}$ & $\begin{array}{c}\text { 2nd year } \\
\text { JHS }\end{array}$ & $\begin{array}{c}\text { 3rd year } \\
\text { JHS }\end{array}$ & $\begin{array}{c}\text { Total } \\
\text { JHS }\end{array}$ & SHS \\
\hline India & 1 & 1 & & 2 & 6 \\
Singapore & & 1 & 1 & 1 & 2 \\
Bangladesh & 1 & & & 1 & 1 \\
Jamaica & 1 & 1 & 2 & 2 \\
Kenya & & & & 3 \\
South Africa & & & & 2 \\
Philippines & & & & \\
Sri Lanka & & & & & 2 \\
\hline
\end{tabular}

Note: In addition to the countries listed above, Malaysia, Nigeria, Pakistan, Rwanda, Zimbabwe, and the Dominican Republic were each found once in SHS material.

Nations of the Expanding Circle

As Crystal states, the Expanding Circle includes countries that recognize "English as an international language." In addition, "they do not have a history of colonization by members of the Inner Circle, nor have they given English any special administrative status" (1997, p. 54). For example, "it includes China, Japan, Greece, Poland, and (as the name of this circle suggests) a steadily increasing number of other states" where "English is taught as a foreign language" (p. 54). Table 3 lists all the nations in the Expanding Circle from which cultural items have been identified in textbooks. As can be seen, firstly, although there are many nations in this category, including many lesser-known countries, Japan strongly dominates the Expanding Circle. As Figure 3 shows, Japanese cultural items stand at approximately $64 \%$ in JHS. Although this figure goes down 
to $44 \%$ in SHS, it still occupies nearly half the total of this circle. Secondly, in terms of the other nations, Asian countries predominate. For example, China and Korea, which are considered the primary neighbors of Japan, increase in frequency in SHS although the percentages are still not large.

Table 3. Nations in which Various Aspects of Culture are Found: The Expanding Circle

\begin{tabular}{|c|c|c|c|c|c|c|c|c|c|c|c|}
\hline \multicolumn{2}{|c|}{$\begin{array}{c}\text { 1st Year } \\
\text { JHS }\end{array}$} & \multicolumn{2}{|c|}{$\begin{array}{c}\text { 2nd Year } \\
\text { JHS }\end{array}$} & \multicolumn{2}{|c|}{$\begin{array}{c}\text { 3rd Year } \\
\text { JHS }\end{array}$} & \multicolumn{2}{|l|}{$\begin{array}{l}\text { Total } \\
\text { JHS }\end{array}$} & \multicolumn{4}{|c|}{ SHS } \\
\hline Japan & 15 & Japan & 13 & Japan & 18 & Japan & 46 & Japan & 66 & Sweden & 2 \\
\hline China & 4 & Korea & 2 & Korea & 2 & China & 6 & China & 10 & Switzerland & 2 \\
\hline Mexico & 1 & China & 1 & China & 1 & Korea & 4 & Korea & 1 & Taiwan & 2 \\
\hline Brazil & 1 & Mongolia & 1 & Turkey & 1 & France & 2 & Brazil & 5 & Turkey & 2 \\
\hline France & 1 & Cambodia & 1 & Sudan & 1 & Italy & 2 & France & 5 & Vietnam & 2 \\
\hline Italy & 1 & Guatemala & 1 & France & 1 & Turkey & 1 & Spain & 5 & Angola & 1 \\
\hline Finland & 1 & Germany & 1 & Russia & 1 & Cambodia & 1 & Germany & 4 & Bosnia & 1 \\
\hline Yugoslavia & 1 & Sweden & 1 & & & Mongolia & 1 & Thailand & 4 & Bulgaria & 1 \\
\hline & & Italy & 1 & & & Mexico & 1 & Tibet & 4 & Colombia & 1 \\
\hline & & & & & & Brazil & 1 & Cambodia & 3 & Costa Rica & 1 \\
\hline & & & & & & Sweden & 1 & Mozambique & 3 & Holland & 1 \\
\hline & & & & & & Germany & 1 & Nepal & 3 & Hong Kong & 1 \\
\hline & & & & & & Russia & 1 & Egypt & 2 & Iceland & 1 \\
\hline & & & & & & Sudan & 1 & Indonesia & 2 & Iran & 1 \\
\hline & & & & & & Guatemala & 1 & Italy & 1 & Myanmar & 1 \\
\hline & & & & & & Finland & 1 & Norway & 1 & Saudi Arabia & 1 \\
\hline & & & & & & Yugoslavia & 1 & Russia & 2 & & \\
\hline
\end{tabular}




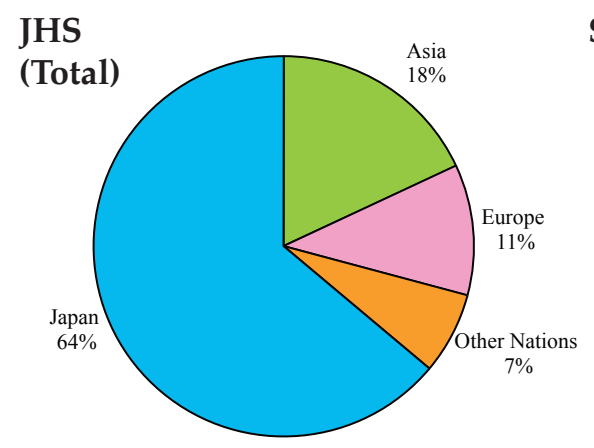

SHS

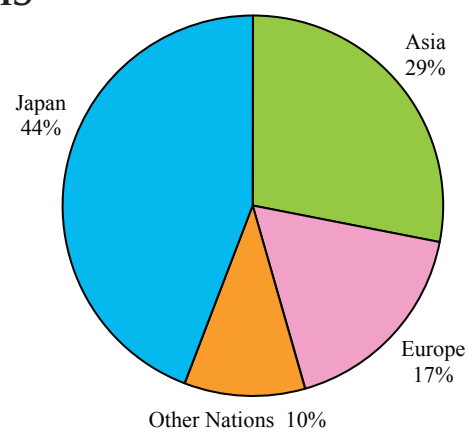

Figure 3. Nations Identified in the Expanding Circle Classified into Regions

\section{Nations: Comparison between the Three Circles and Japan}

So far, the results of this investigation have been presented at the level of individual nations in the three Circles. However, in order to understand the teaching of culture from a broader perspective, the circles themselves are compared in this section. In addition, since the 2003 Ministry of Education guidelines claim that it is important for Japanese students to deepen their understanding of their own culture for effective intercultural interactions, the Expanding Circle has been further subdivided into two categories: Japan and the other Expanding Circle countries.

Two significant facts emerge from these results. As can be seen in Table 4, first, the number of nations found in English textbooks for SHS is higher than in JHS. This suggests that there may be more cultural elements covered in SHS than in JHS. In fact, the average number of topics per unit for SHS is 2.10, compared with 1.36 for JHS. Secondly, as can be seen in Figure 4, the distributive percentages in terms of Japan and the Inner Circle decline by approximately $10 \%$ in SHS. In other words, in JHS, units on Japan amount to $36 \%$, while those dealing with the Inner Circle stand at 38\%. In contrast, in SHS these figures are $26 \%$ and $30 \%$, respectively. These declines imply an increased focus on the Expanding Circle (not including Japan) in SHS, suggesting that the teaching of culture may have a more global emphasis as students mature. 
Table 4. Nations in which Various Aspects of Culture are Found: The Three Circles and Japan

\begin{tabular}{lccccc}
\hline Circles & $\begin{array}{r}\text { 1st Year } \\
\text { JHS (33) }\end{array}$ & $\begin{array}{c}\text { 2nd Year } \\
\text { JHS (31) }\end{array}$ & $\begin{array}{c}\text { 3rd Year } \\
\text { JHS (29) }\end{array}$ & $\begin{array}{c}\text { Total } \\
\text { JHS (93) }\end{array}$ & SHS (151) \\
\hline Inner & 21 & 17 & 14 & 52 & 76 \\
Outer & 3 & 3 & 1 & 7 & 24 \\
$\begin{array}{l}\text { Expanding } \\
\text { **Not including }\end{array}$ & 10 & 9 & 7 & 26 & 85 \\
Japan & & & & & \\
Japan & 15 & 13 & 18 & 46 & 66 \\
Total & 49 & 42 & 40 & 131 & 251 \\
\hline
\end{tabular}

Note: Numbers in parentheses are total chapters.
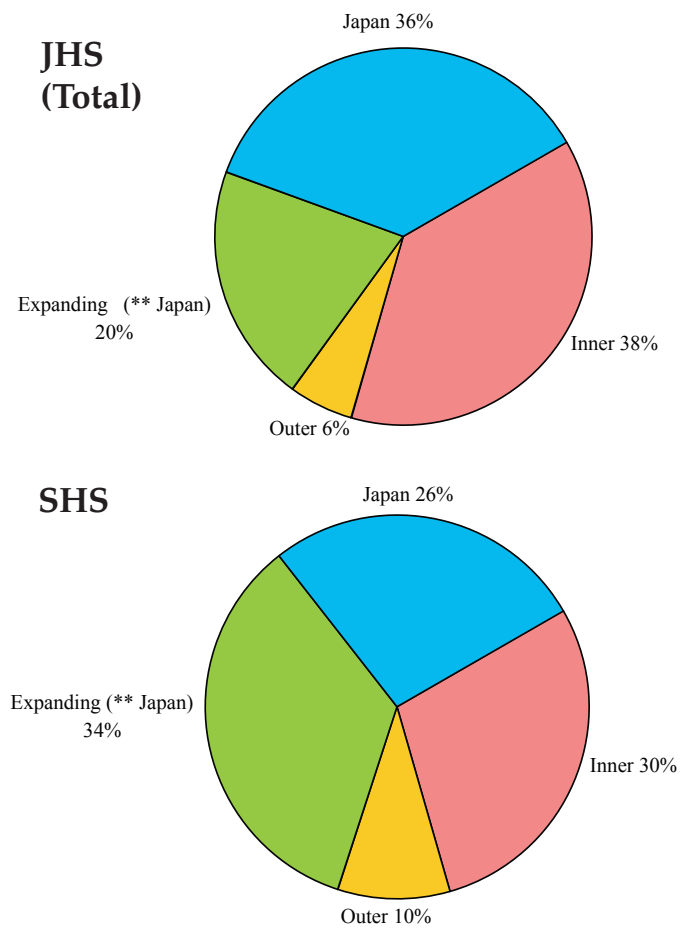

Figure 4. Table 4 in Graphic Form 
In classifying the total results of JHS into grades, one clear tendency is that the focus in teaching culture is on Japan when students reach an advanced level. By contrast, the Inner Circle is emphasized when students are at an entry level. As Figure 5 shows, units on Japan stand at $31 \%$ in the 1st year of JHS, rise slightly to $33 \%$ in the 2nd year, and go up to $46 \%$ in the 3 rd year. In terms of the Inner Circle, these percentages are $43 \%, 36 \%$, and $33 \%$, respectively.

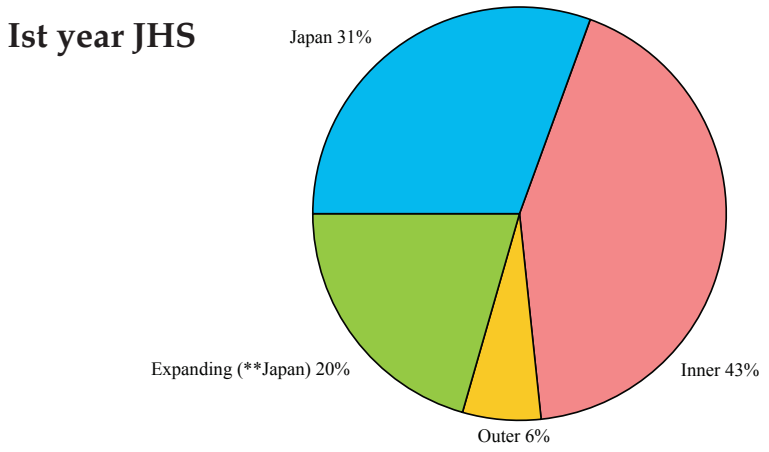

\section{2nd year JHS}

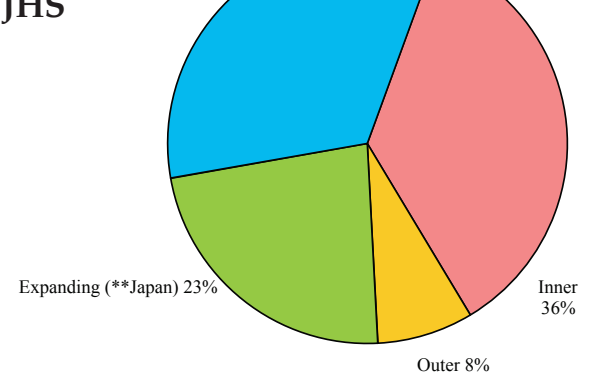

3rd year JHS

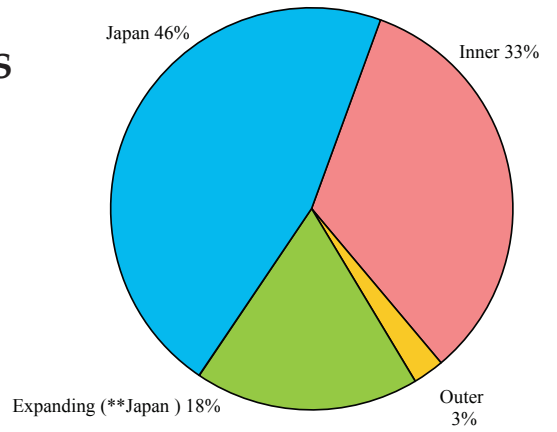

Figure 5. Table 4 in Graphic Form (All Grades of JHS) 
Taking the above information into consideration, the focus on the teaching of culture appears to involve three steps in secondary schools. Firstly, the Inner Circle and its relation to native speakers of English is introduced, then topics related to Japan are taught, and finally starting in SHS, the Expanding Circle (not including Japan) is presented.

\section{Discussion}

Regarding the nations in which English is used, there are four observations that can be made. As can be seen in Table 1, Nations of the Inner Circle, the USA appears most frequently in English textbooks for both JHS and SHS. In a previous study, Kitao (1979) maintained that it is commonly believed that "American culture has been emphasized in English instruction in Japan" (p. 90). However, his research strongly focused on culture related to America and showed a contradiction between this belief and the reality of English textbooks used in the classroom. He concluded that "Japanese students were taught very little about American culture in English courses of any level, so their understanding of American culture was quite limited" (p. 91). Approximately 20 years after Kitao's investigation, however, Kiryu et al. found different results, maintaining that at present "the focus is on America and Japan, although a relatively wider range of regions in the world are referred to" in English textbooks for SHS (1999, p. 23; my translation). Nevertheless, in evaluating textbooks from the standpoint of American or British English, the percentages of cultural items seem to be almost equally distributed. Thus, the results of this investigation partially agree with the study conducted by Kiryu et al. (1999). However, the findings also show that the distribution is much more equally divided than previously thought.

Secondly, as Table 2, Nations of the Outer Circle, demonstrates, the frequencies of nations involved are quite low, even though Japan has close relations with a number of these countries economically and politically (e.g., Singapore, Malaysia, India). The 2003 Ministry's guidelines do not address political issues, however. They simply state that "it is important to understand not only the nations involved but also the people who live in these nations with other languages and cultures" (1999, p. 133; my translation). Nevertheless, it is imperative for young Japanese to learn about the nations of the Outer Circle because they are close neighbors of Japan. Concerning this issue, it would be better if more information on these Outer Circle countries were provided in the textbooks. 
Thirdly, as Table 3, Nations of the Expanding Circle, shows, as would be expected, that Japan dominates this particular circle in English textbooks for both JHS and SHS. Nevertheless, it is gratifying to see cultural information from Japan's closest neighbors included as well. China and South Korea are also present in this circle, although the percentages are not very high. One of the reasons for the inclusion of these countries can perhaps be explained by examining statistics released by The Japan Times (Matsubara, 2003, p. 6) which show that the population of overseas students from China residing in Japan totals 58,533, the highest number from any nation, with South Korea second. In addition, when Japanese students study abroad, the USA still seems to be the preferred destination followed by China, England, South Korea, and Australia in descending order (Ministry of Education, Culture, Sports, Science and Technology, 2001, p. 39).

Fourthly, the percentage of nations belonging to the Expanding Circle goes up substantially in SHS in comparison with JHS. At the same time, in terms of cultural items related to Japan, the frequency declines in SHS. Thus, the emphasis on students' learning about their own culture in JHS seems to shift to an emphasis on greater understanding of other cultures in SHS.

\section{Conclusion}

Parmenter and Tomita (2001) point out that "the textbook authorization system [in Japan] means that publishers have to follow [the Ministry's] guidelines closely in order to have their books authorized for use in schools" (p. 134). Nonetheless, in the 2003 Ministry guidelines, there are no detailed instructions about which nations should be included in the textbooks; the only directions to be found are expressions such as "cultures of Japan and the rest of the world" or "countries that use the foreign languages" (Ministry of Education, Culture, Sports, Science and Technology, 2003, p. 14). Consequently, it is not clear on what grounds the writers of these textbooks have made judgments on the inclusion, or lack of inclusion, of specific nations appearing in English textbooks.

Parmenter and Tomita (2001) also state that "although there is no systematic inclusion of cultural content in the curriculum, analysis of textbooks reveals that there is a bias towards the USA, both in terms of language (US idioms, spelling, accent, etc.) and in terms of cultural information included." However, the results of this study partially disagree with these claims, since the percentages of cultural items related to 
American and British spheres seem to be almost equally distributed in the Inner Circle.

On the other hand, the results from the standpoint of the three concentric circles suggested by Kachru reveal that there are still biases and misconceptions. Firstly, there is a marked lack of emphasis on nations in the Outer Circle in comparison with countries in the Inner Circle. The countries in the Outer Circle appear the least frequently in English textbooks (6\% in JHS, with a slight rise to $10 \%$ in SHS), even though Japan is currently attempting to create closer ties with these nations. Secondly, in addition to nations in the Outer Circle, while Japan dominates cultural items in English textbooks for both JHS and SHS, the frequency of countries (except for Japan) in the Expanding Circle is rather low. Since Japan and other nations in the Expanding Circle have important ties as political allies and trading partners, it would have been better if the nations of the Expanding Circle (in addition to the Outer Circle) had received a stronger focus.

In fact, demands for further understanding of the nations in both the Outer Circle and the Expanding Circle have arisen because Japan has experienced a transition in terms of its English needs in the last few decades. Twenty-seven years ago, Kenji Kitao (1979) stated that "more Japanese people are encountering more American people, products, information, and culture on a daily basis than ever before" (p. 90), adding that "thus, better understanding and communication between the citizens of the two cultures is necessary" (p. 90). Hence, in the past, cultural issues related to native speakers of English were the main focus because English was regarded as a language for communicating with people from Western countries. At present, however, as English has become a global language which is used for interacting with people all over the world, it would be beneficial for young Japanese people to learn about a variety of cultures, not just those related to Inner Circle countries. Thus, a better balance in terms of the nations that are included in the textbooks would certainly enhance their content.

\section{Suggestions for Further Research}

In conclusion, this study has attempted to analyze English textbooks used in Japanese secondary schools from the perspective of the three concentric circles suggested by Kachru. However, there are many issues that were beyond the scope of this investigation and deserve further attention. First, it would certainly be useful to interview Japanese English teachers 
themselves on the effectiveness of the Ministry's ambiguous guidelines as well as their views on the value of the way current English textbooks "teach" culture. In addition, although these guidelines are the basis upon which teachers conduct their lessons in Japan, according to Parmenter and Tomita (2001), "there are no teaching guidelines [emphasis added] concerning cultural content or the development of intercultural competence" (p. 134). In other words, coherent directives in terms of guidance on the teaching of culture are lacking and thus it is hoped that interviewing classroom teachers will provide a variety of perspectives on this matter. Second, as Assistant Language Teachers (ALTs) from other countries often participate in lessons these days, and play an important role in teaching culture, it may well be valuable to solicit their opinions and ideas. Finally, since "textbooks form the central part of foreign language classes, and this system ensures that Ministry of Education guidelines reach individual students directly" (2001, p.134), it may also be necessary to investigate the students' point of view to determine which countries are of interest to them and whether or not their preferences agree with those of their instructors. Therefore, understanding a variety of perspectives on the teaching of culture through English, particularly those provided by teachers and students, would be beneficial in making progress in designing textbooks that can enhance intercultural understanding in Japan in the future.

\section{Acknowledgments}

I would like to express my deep gratitude to Dr. Roger J. Davies of Hitotsubashi University for his encouragement and detailed instruction on this paper. I would also like to thank Professor Osamu Ikeno of Ehime University for his comments on this study. In addition, a special word of thanks should also go to my colleagues, Takako Morimoto, Toshiyuki Nitta, and Manami Takata, who discussed the manuscript with me and encouraged me to accomplish this investigation.

\section{Notes}

1. The Japanese Ministry of Education was called Mombusho (the Ministry of Education) until 1999. Thereafter, the name was changed to Mombukagakusho (the Ministry of Education, Culture, Sports, Science and Technology). For the purpose of this study we will simply refer to the Ministry of Education. 
2. According to Ashikaga et al. (2001, p. 3), the four categories are as follows:

(1) Target Culture (T), which represents cultures where English is spoken as a first language, (2) Source Culture (S), which represents Japanese culture, (3) Target and Source Culture (T\&S), which represents a comparison of $T$ and $S$, and (4) International Culture (I) which represents the culture of countries other than T and S, or comparisons of other countries with either T or S. Global issues are also included in this type.

3. Nation specific indicates "a situation in which a nation becomes not only a background but also a main topic in a unit." Nation nonspecific, by contrast, "describes a situation in which topics not only center on individuals but also do not refer to nations, such as in biographies and novels. These topics are also common throughout the world,... and include environmental issues, world peace, ethics, morals, and science" (Kiryu et al., 1999, pp. 21-22; my translation).

4. Although English courses in junior high schools are obligatory, at the high school level only the subjects English I and Oral Communication I are compulsory subjects. Thereafter, there are divergent options in terms of students' choices. Regarding textbook selection for senior high school, this author decided to choose one of the compulsory subjects as a representative sample of the teaching of culture for this investigation. According to Watanabe in Naigai Kyouiku (2002), English textbooks for English I have been used more than those for Oral Communication I; therefore, English textbooks for English I were chosen. In this way, an equivalent sample of compulsory textbooks was evaluated across junior high and senior high school levels.

5. In the following sections, terminology such as "1st year JHS" or "SHS" has been used in place of "the first year of junior high school" or "senior high school" for the sake of brevity.

6. Great Britain does not include Northern Ireland. In reality, however, as the terms "the UK" and "Britain" are often used interchangeably, they were considered to be synonymous in this investigation. 


\section{References}

Ashikaga, T., Fujita, R., \& Ikuta, Y. (2001). A study of cultural aspects in Japanese EFL communication textbooks. JACET Bulletin, 33, 1-10.

Browne, C., \& Wada, M. (1998). Current issues in high school English teaching in Japan: An exploratory survey. Language, Culture, and Curriculum, 97-112.

Crystal, D. (1997). English as a global language. Cambridge: Cambridge University Press.

FirstStep.(2004,December 11). The Japan Times Weekly Online. Retrieved February 17, 2004, from http:/ / www.japantimes.co.jp/weekly/ed/ed20041211a1.htm

Horibe, H. (2000). Is English Cinderella, a kidnapped or adopted child, or Godzilla?: Diverse perspectives and pedagogical conflicts. JALT Journal, 22 (2), 326-340.

Kachru, B. (1989). Teaching world Englishes. Cross Currents: An International Journal of Language Teaching and Cross-Cultural Communication, 16 (1), 15-21.

Kiryu, N., Shibata, T., Tagatani, H., \& Wada, T. (1999). Koutougakkou eigo kyoukasho no bunseki [An analysis of senior high school textbooks for English I]. The Language Teacher, 23 (4), 21-23.

Kitao, K. (1979). The present situation in the teaching of American culture in English course in Japan: Analysis of junior and senior high school English textbooks in Japan. Doushisha Studies in English, 21, 90-130.

Matsubara, H. (2003, July 26). Symposium eyes ways to attract foreign students. The Japan Times, p. 6.

Mombukagakusho [Ministry of Education, Culture, Sports, Science and Technology] (2001). Wagakuni no ryugakuseiseido no gaiyou: Ukeire oyobi haken [An outline of the system for overseas students in our country: Acceptance and dispatch]. Retrieved January 10, 2004, from MEXT database http: / / www. mext.go.jp/b_menu/houdou/16/05/04071201/all.pdf

Mombukagakusho [Ministry of Education, Culture, Sports, Science and Technology] (2003). The course of study for foreign languages. Retrieved September 7, 2003, from MEXT database http:/ / www.mext.go.jp/english/ shotou/030301.htm

Mombusho [Ministry of Education]. (1999). Koutougakkou gakushu shidou youryou kaisetsu: Gaikokugo hen, Eigo hen [Description of the course of study for senior high schools: Foreign language education, \& English language education]. Tokyo: Kairyudo.

Parmenter, L., \& Tomita, Y. (2001). Virtual intercultural competence: A programme for Japanese elementary school students. In M. Byram, A. Nichols, \& D. Stevens (Eds.), Developing intercultural competence in practice (pp. 133-145). Clevedon: Multilingual Matters Ltd.

Sochi, M. (2001). Dougutoshiteno gaikokugoto ibunkarikai [Foreign language as a tool and intercultural understanding]. The English Teacher's Magazine, 50 (7), 26-28. 
Watanabe, A. (2002, December, 3). Shinkyoka "joho' joho" wa A ga 84\% [The new subject "information": Information A accounts for 84\%]. 2003 nendo koukou kyoukasho saitakujoukyou, Momkasho matome [Senior high school textbooks adopted in 2003: A report from the Ministry of Education, Culture, Sports, Science and Technology]. Naigai Kyouiku, 5347, 10-19. 